\title{
Transatlantica
}

Revue d'études américaines. American Studies Journal

$1 \mid 2010$

American Shakespeare / Comic Books

\section{Living-with Shakespeare?}

(Three American experimental poets' compositions with Shakespeare's sonnet 130)

\section{Vincent Broqua}

\section{(2) OpenEdition}

1 Journals

\section{Édition électronique}

URL : https://journals.openedition.org/transatlantica/4815

DOI : $10.4000 /$ transatlantica.4815

ISSN : 1765-2766

Éditeur

Association française d'Etudes Américaines (AFEA)

\section{Référence électronique}

Vincent Broqua, "Living-with Shakespeare? », Transatlantica [En ligne], 1 | 2010, mis en ligne le 13 octobre 2010, consulté le 10 février 2023. URL : http://journals.openedition.org/transatlantica/4815 ; DOI : https://doi.org/10.4000/transatlantica.4815

Ce document a été généré automatiquement le 10 février 2023.

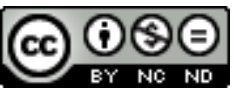

Creative Commons - Attribution - Pas d'Utilisation Commerciale - Pas de Modification 4.0 International - CC BY-NC-ND 4.0

https://creativecommons.org/licenses/by-nc-nd/4.0/ 


\section{Living-with Shakespeare?}

(Three American experimental poets' compositions with Shakespeare's sonnet 130)

\section{Vincent Broqua}

\section{Malediction}

1 What if Shakespeare were dead? On Shakespeare's tombstone in the church of Stratford-upon-Avon, the well-known inscription is addressed to the gravedigger (Schoenbaum 3) as well as to the passer-by who, inevitably, becomes a reader and sees his present future in this text from the past:

Good friend for Jesus' sake forbear,

To dig the dust enclosed here!

Blessed be the man that spares these stones,

And cursed be he that moves my bones.

2 With this malediction, Shakespeare, if it is Shakespeare, formally forbids anyone to desecrate his monument, to probe into his shrine, and to profane his crypt. There seems to be an injunction from the grave not to touch Shakespeare's physical remains. The tombstone and the malediction point towards Shakespeare's oeuvre and seem to signal the very impossibility that surrounds it. With this inscription, it is inconceivable to even dare think of the body, or, in other words, dare think of the fiction of a soul that lies in peace. Thus, if one accepts such an analogy between the reference to the physical body and the body of work, between the final, perpetual and solemn four iambic lines and the pages printed in the folio, as well as between the death monument and the monumental reputation, then one is instructed never to touch and delve into the work and into Will's will. If ever it was to be touched, it should be done with such respect towards the authorial voice and authoritative ghost speaking here that it would leave its cadaver to its essential rigor mortis.

3 From the tombstone, then, there seems to be a form of diction, which enjoins all potential readers never to move the rigor of the text out of its joints, lest one should transform it into condemnable diction or malediction. 
4 It therefore seems that the angst of the future readers is inscribed in the very diction of the dead and that the deceased speaks in the future of their text. Such angst grips the actor when he is faced with parts that are too vast for him, or the critic who will never be able to cope with the intricacies, subtleties and virtuosity of Shakespeare's text. Typically, such a critic is plagued with a literary form of tinnitus after hearing too many Shakespearean echoes woven into the texts of others without knowing exactly if he should indeed assign these linguistic ghosts and literary wraiths to Shakespeare's haunting texture. Such angst also troubles the British as well as the American poet, baffled as they are by an author who, it is often supposed, has written everything because he is the essence of all literature, the universal oeuvre, or, in other words, the untouchable body. From this point of view, any writer inevitably seems a paradoxical incapacitated blasphemer.

\section{The conditions of the possible}

"If" and "seems" indeed. This article does not attempt to deny that Shakespeare - the man - is dead, but the hypothetical mode that I espoused is a way to both endorse the role of the poor player and, assuming the mask of another critic, point towards some of the paradoxes of an essential Shakespeare as developed by Harold Bloom in his introduction and preface to the second edition of The Anxiety of Influence. In these two texts, I will argue, Shakespeare is precisely dead, in that his text is confined to the monumental rigor of an exclusive essentialist thought.

6 In an endeavour to consider the conditions of possibility of Shakespeare today, this article wishes to reconsider the prerequisites of Bloom's theory of influence as he articulates them with reference to Shakespeare. This consideration will enable us to attempt to propose another model for the possibility of Shakespeare's actualisation in contemporary experimental poetry, chiefly in three American poets' reinterpretations of or writing-with Shakespeare's Sonnets.

7 This argument is part of an incipient larger text on Shakespeare in the avant-gardes and experimental poetries of the United States. To put it briefly, the argument is to attempt to forge a different perspective on the relation between Shakespeare and experimental poetics. It attempts to diverge from a theory which posits - like Bloom's and its avatars - that literature is a tragedy originating in Shakespeare's essential and universal grandeur. This article thus wishes to begin to dig a place, elsewhere, which it does not invent: a place where it is possible to move the bones of Shakespeare via the delineation of other forms of diction than the malediction, forms in which the writer is not always at odds with Shakespeare. This perhaps amounts to wishing to articulate the conditional possibility of Shakespeare's ghost in the present.

\section{Universal Shakespeare, or tragic vision: the present as death of Shakespeare?}

8 It is not primarily for his general theory of influence that I endeavour to make an excursus through Bloom's text-others have already challenged his position ${ }^{1-}$ but rather for one of the principles undergirding his text on Shakespeare, i.e. a conception of literature as the tragedy of a lost and perverted origin. 
In his introduction and preface to the second edition of The Anxiety of Influence, Bloom's underlying argument is that literature, and poetry notably, is perpetually declining: "the diminishment of poetry seems to me an inevitable realization" (10). Such a decline and loss of momentum originates in the Renaissance and in what he sees as an unsurpassed point, thus condemning future literature to tread the path of what he calls "the death of poetry" (10): "poetry in our tradition, when it dies, will be self-slain, murdered by its own past strength" (10). Bloom's second edition of The Anxiety of Influence is particularly important for us since he devotes a large part of his preface to Shakespeare. Building on the idea of the coming demise of poetry, Bloom places himself within the long line of readers who from the early $18^{\text {th }}$ century to the Romantics have transformed Shakespeare into a supernatural Genius (Bate 1997). Indeed, in almost Hugolian fashion", he states that "Shakespeare belongs to the giant age before the flood" (11). Like the romantics who transformed Shakespeare into a God, Bloom thus rhetorically turns Shakespeare into an antediluvian patriarch of literature, before the Fall of literature. "Shakespeare always was there before us" (xxv). And one is even tempted to read Shakespeare as belonging to a blessed age before the Fall, to the Eden of literature. Indeed, to Bloom, Shakespeare is an absolute ("he thought all thoughts" [xxviii], or "Shakespeare is the largest instance in the language of a phenomenon that stands outside the concern of this book: the absolute absorption of the precursor" [10]) and a universal of literature, or even the whole of literature: "Shakespeare (...) quite simply not only is the Western Canon; he is also the World Canon" (xv). Bloom's Shakespeare is the universal Shakespeare, to such extent that Bloom seems to forget that Shakespeare, precisely, wasn't always there as the figure of a universal author: to Bloom's view of Shakespeare's imperial domination, "Shakespeare's influence began almost immediately and has prevailed these four centuries since he died" (xxix), one should oppose a careful reading of the history of the reception of Shakespeare, which questions Bloom's vision of Shakespeare's eternal dominion. To repeat the well-known argument in a few words, the idea of Shakespeare's universality started in the $18^{\text {th }}$ century and prevailed into the $19^{\text {th }}$ century when Britain was establishing its Empire. Among other things, Shakespeare's transformation into a superlative Genius was an instrument of the United Kingdom's empire'.

To found a true and genuine literary history - "accurate literary history" (10) - of true literature - "authentic, high literature" (xvii) -Bloom opposes the apparent common sense of the peerless universality of Shakespeare to anyone and any thought trying to envisage Shakespeare differently. He specifically expresses his strong opposition to socalled "French theory" and to the French: "The French have never valued originality" or, again, "they still esteem Shakespeare rather less than do the Indonesians or the Japanese or the Americans" (xv) ${ }^{4}$. What matters here is not so much his rant against the French, as a view that reduces the other to a fixed totality, be it the French or Shakespeare.

11 Bloom's following dictum encapsulates what he reproaches French theory, feminism, New Historicism and most of the criticism of the last forty years with: "what we insist upon calling 'theory' dogmatizes that no one ever had or even will have a self of her or his own. That seems to me an unamiable fiction" (xlvi). Going back to Shakespeare's inscription, one might paraphrase Bloom's own mot d'ordre as "don't dig, don't move his bones." This wouldn't be too far from Bloom's own ventriloquy of the injunction on the Bard's tombstone, when the American critic warns 
the potential grave-diggers and those he calls "the resenters"5: "Shakespeare will not allow you to bury him, or escape him, or replace him" (xviii). The "you" Bloom resorts to is once again dictated from a paraphrase of Shakespeare's tombstone. Bloom typically doesn't seem to include himself in this "you." His injunction - ghost-writing Shakespeare's - and the polemical choice of pronouns informs his essentialism - "our true relation to Shakespeare" (xviii) - articulated to a desire to pass a definitive judgment on Shakespeare's psyche: "Marlowe inspired in him both ambivalence and anxiety" (xxvii, italics mine). His own argument backfires: the preface and introduction in which Shakespeare is mentioned gradually build the very fiction he resents in the "resenters:" to write a biography of Shakespeare and delve into his psyche, can only be a tentative endeavour, as Schoenbaum ${ }^{6}$ has perfectly shown.

Besides, his view or his vision of literature can be situated within the scope of the romantic interpretation of Shakespeare, foregrounding imagination. His rhetoric in the text he devotes to Shakespeare suggests that the voice of his authority derives from the voice of Shakespeare's curse and sees Shakespeare as untouchable, confined within the eternity of his tombstone. This authoritative voice come from the dead logically rephrases the words of the malediction and turns the gravediggers into the metaphoric perpetrators of Shakespeare's great doom: "our resenters [...] turn to proclaiming what only can be called the Death of Shakespeare" (xviii). The death of criticism, the death of poetry, the death of Shakespeare...

Then, what's left of Shakespeare if he is to be touched with godlike reverence only? What's left of criticism if any reinterpretation that does not espouse the supposed authentic voice of Shakespeare amounts to a crime against the absolute god of western literature? How about poets if poetry is dead? And isn't poetry precisely dead if it cannot touch and approach Shakespeare?

To speak for Shakespeare, to take his voice, to be his ghost and to say that Shakespeare is universal and that he is the tragic origin of all literature stifles Shakespeare's text. This petrifies Shakespeare into a commander of literature with all its classic trappings. Is this the only way with ghosts? What does it take, in the words of Jacques Derrida, to "learn to live with ghosts," i.e. to try to live "in the upkeep, the conversation, the company, or the companionship, in the commerce without commerce of ghosts. To live otherwise, and better" (xviii)? How can one endeavour to conceive "the virtual space of spectrality," (11) which is as far as possible from the stable rigor of the canon and propose, rather, questions enabling one to "think of [...] the possibility of the ghost" (Derrida 34), and of the possibility of the ghosts of Shakespeare's text. Such an open conception of literature and multiple questions are perhaps articulated by Melville when, speaking of Hawthorne, he argues that: "in Shakespeare's tomb lies infinitely more than Shakespeare ever wrote. And if I magnify Shakespeare, it is not so much for what he did do, as for what he did not do, or refrained from doing" (244). Shakespeare did not map the whole world of literature, he left uncharted territories whose blank spaces are delineated by what he wrote. Still mentioning Shakespeare's tomb and crypt, Melville's position allows literature to grow and be, without creating an exclusive father-son relationship. The reverence endures, but Melville qualifies the idea of an absolute god of literature. With the three following texts, this article endeavours to tentatively draw another response to Shakespeare's work and ghosts: one that does not appropriate the ghost of Shakespeare to speak for him and pretend that there is one Shakespeare forever. 


\section{Three texts +1}

$$
\text { pleasing sound. }
$$

saw

$$
\text { walks }
$$

I think

with

My Mickey Mouse ears are nothing like sonar. Colorado is far less rusty than Walt's lyric riddles. If sorrow is wintergreen, well then Walt's breakdancers are dunderheads. If hoecakes are Wonder Bras, blond Wonder Bras grow on Walt's hornytoad. I have seen roadkill damaged, riddled and wintergreen, but no such roadkill see I in Walt's checkbook. And in some purchases there is more eration than in the bargains that my Mickey Mouse redeems. I love to herd sheep, yet well I know that muskrats have a far more platonic sonogram. I er saw a googolplex groan. My Mickey Mouse, when Walt waddles, trips on garbanzos. And yet, by halogen-light, I think my loneliness as reckless as any souvenir bought with free coupons.

air

$$
\text { asked, red }
$$

in

some

the breath that speak

sun -

more

white, why

C Stephen Ratcliffe and O Books, 1989

$>$ Jen Bervin $(2006,102)$

130

My mistress' eyes are nothing like the sun;

Coral is far more red than her lips' red.

If snow be white, why then her breasts are dun;

4 If hairs be wires, black wires grow on her head.

I have seen roses damasked, red and white,

But no such roses see I in her cheeks;

And in some perfumes is there more delight

8 Than in the breath that from my mistress reeks.

I love to hear her speak, yet well I know

That music hath a far more pleasing sound.

I grant I never saw a goddess go:

12 My mistress when she walks treads on the ground.

And yet, by heaven, I think my love as rare

As any she belied with false compare.

Jen Bervin, Nets, (C) Ugly Ducking Presse, 2004 


\section{$>$ William Shakespeare, sonnet 130}

My mistress' eyes are nothing like the sun; Coral is far more red than her lips' red. If snow be white, why then her breasts are dun; If hairs be wires, black wires grow on her head. I have seen roses damasked, red and white, But no such roses see I in her cheeks; And in some perfumes is there more delight Than in the breath that from my mistress reeks. I love to hear her speak, yet well I know That music hath a far more pleasing sound. I grant I never saw a goddess go: My mistress when she walks treads on the ground. And yet, by heaven, I think my love as rare As any she belied with false compare. characteristics uncovered by Booth. For instance, the poem shifts from one motif to the other, sometimes interlocking them. Yet, though it concludes with an apparently easier, clearer twist, its semantic syncopation first breeds nonsense, which the reader could simply characterise as playful and funny with respect to Shakespeare's text. And one could very well stop right there, but Mullen's text offers more. For example, the motif of sound recurs in the first, sixth and seventh sentences as lexical associations 
such as "sonar," "sonogram" or "groan." This constant reference to sound leads to phonetic distortions and paronomasias guided by the haunting presence of Shakespeare's text in Mullen's semantic arabesques. Indeed, one hears "heard" in "I love to herd Walt's sheep." This unconventional reading is prompted by the Shakespearean line parodied by Mullen: "I love to hear her speak," and, reading it from another perspective, Shakespeare's text is not restricted to being a text from the past and Mullen's to being a text written in the present. Shakespeare's text haunts the poem and our reading of the text into agrammaticality, but conversely the ghostly emergence of Shakespeare's "hear" in the present of Mullen's text is contaminated into "heard" by Mullen's poem.

Moreover, such dual processes of contaminated nonsense preside over the poem, and it is precisely an oscillation between disjunctive poetics and contamination that gradually defines what precarious meaning the text has. The incongruity of the metaphors used by Petrarchan poetry and mocked by Shakespeare as pompous ("I grant I never saw a goddess go" 1. 11) and false (1. 14) through a rhetoric of the paradox, is reinforced by Mullen's disjunctive poem: for instance, whereas Shakespeare's reference to the mistress is clear ("My mistress" frames the first twelve lines, and "her" and "she" create a clear pronominal system), Mullen disrupts reference by her use of Mickey Mouse and Walt for "Mistress" and "her" respectively. Therefore the "mistress" becomes a supposedly male anthropomorphic animal character and the pronoun referring to the subject of Shakespeare's poem becomes the first name of the creator of the famous comic book icon. Mullen doesn't respect the substitutive principle here: she should have used a word starting with " $h$ " instead of "Walt". This breach in the compositional process underscores even further the sense of this nonsense: the mistress of Shakespeare's poem has been split and distorted into the creature and its creator, suggesting an uncanny interdependence between them, expressed in "My Mickey Mouse, when Walt waddles, trips on garbanzos." In Shakespeare's text, the attempt was to free the mistress-muse from her subjection by the creator to the reifying stereotypes and poetic appropriation of the blason, turning the lady into an object of beauty typical of the Renaissance (white skin, blond hair, red lips, harmonious voice and goddess-like gait). Similarly, Mullen's text states the creature's alienating subjection to the creator ("waddles," "trips") and yet tries to free the Mouse-muse from its fate as the moral, happy and rather smoothly pleasant icon of an American "globe-spanning entertainment conglomerate" (Levin 5). In the poem, Mickey and Walt's figures are deconstructed through wordplay. For instance, "Blond Wonder Bras grow on Walt's hornytoad" functions like a surrealist collage. Provided the "hornytoad" refers to Mickey, Walt's creature has become a "hornytoad," a word fraught with ominous eroticism very far from Mickey's. A product of feminine cosmetic culture is literally grafted onto its body ("grow"), thus metamorphosing Mickey's masculine gender into a monstrous, eerie and uncertain composition. Mickey's happy humour is distorted into irony by the juxtaposition of an animal and a product of mass consumption thus perhaps highlighting the devastation produced by the society of the spectacle. Moreover "black wires" in Shakespeare's 130 is turned here into "blond Wonder Bras." The "black wires," i.e. dark hair, were the very sign of Shakespeare's "dark lady"'s unconventional beauty and contradicted the "fair" or "blond" hair of the Petrarchan ladies. The adjective "blond" in Harryette Mullen's substitution of "black" reverses the unconventional aesthetic of 130 , yet the monstrosity the "blond Wonder Bras" acquires goes back to (is contaminated by or contaminates) Shakespeare's 
original sonnet for it is now the dark lady ${ }^{10}$ who takes the pen to turn the sonnet upside down and to question the beauty of "blond Wonder Bras." She also, it seems, endeavours to change, albeit tentatively, Mickey's fixed image ${ }^{11}$ as an "American archetype of mass culture" (Bonaccorsi 3), and tries to reconsider, for a provisional minute, its transformation into a trade mark by the profit-based strategies of the entertainment industry (Flower).

Though its puns make it funny, though its linguistic arabesques and unforeseen associations add to the comic effect of surprise, though its prose plays with Shakespeare's metrics and preserves Shakespeare's logical structure and some of the poetic characteristics of the original sonnet (the volta and the conclusive form of the couplet are kept), "Variation on a Theme Park" is not a mere game for the sake of entertainment. From its very title, one hears that it is both an exercise and a variation on the theme of the sonnet and, at the same time, the creation of another text in which mass culture, corporate parlance and the world of entertainment are parodied in the same way as Shakespeare's text parodies the strong alienating powers of metaphors and comparisons. Harryette Mullen's text therefore shows the difference between literary games and entertainment, underlying the ethical and political dimension of the former, thus presenting or re-presenting Shakespeare's sonnet not only as a parody but also as a contaminating force for the present.

In an interview where she was asked to discuss her identity, Mullen said that she was "a code-switcher." ${ }^{12}$ It seems that she chooses to parody this particular text to highlight and respond to its original code-shifting effect. With its logical connectors, which she keeps, such as "if then," "like" and "far more," Shakespeare's text questions a poetic tradition whose metaphors and comparisons used to transform women into mere poetic objects ${ }^{13}$. "Variation on a Theme Park" suggests that human beings are in danger of being dehumanised and turned into such objects by entertainment. Mullen moves away from the sonnet and decenters it with prose and parody. And yet, though she transforms its poetic codes (some will say that she defiles or depoeticises the whole sonnet), she also builds an elsewhere in contemporary poetry where Shakespeare's sonnet happens as contaminated and contaminating. She allows us to re-read the text without ever pretending to know the ultimate truth of this sonnet, which, as is well demonstrated by the history of its conflicting interpretations, does not exist. Mullen thus fulfils one of the wishes of the Oulipo: to demystify the creative process and open literature up to new potentialities ${ }^{14}$.

With his alteration of sonnet 130, Stephen Ratcliffe also refrains from seeing Shakespeare's sonnet as an unalterable classic fixed in its rigid authority. Contrary to Harryette Mullen, he uses verse, albeit disarticulated and fragmented. The lines sculpt the page of [where late the sweet] BIRD SANG (1989), allowing the sound of sense to bloom and drift in the explicit non-linearity of its texture. All the poems in the book are obtained by rubbing out some of the linguistic matter of Shakespeare's sonnets. This text is therefore an elliptic and elided sonnet 130 . Ratcliffe's text could very well be an embodiment of Bloom's claim that poetry is dwindling down to its death, since there seems to be virtually nothing left on the page. Has poetry reached such a point of no return that it can only play with a blank page and a few meaningless, unrelated words? And is Shakespeare's death so self-evident that the contemporary poet effectively kills Shakespeare's poetry by way of obliteration, i.e. by an operation that empties the meaning of the formal body of the text while alienating its very soul? 

necessary for the perfect regularity of a grammatical construction, have been taken out from a sentence" (649-650). Stephen Ratcliffe has rubbed out most of the texture of Shakespeare's sonnet, keeping the words where they originally were in the line. This operation, which may be seen as a violent gesture against the sonnets - signalled by the dash at the end of the first line - adds elision to ellipsis. Indeed, "hairs" (1. 4) becomes "air" and "damasked" (1.5) is pared down to "asked." Moreover, though Ratcliffe's text keeps the fourteen lines of the original sonnet, its lines are separated by double spacing, which heightens the dispersion-effect of the poem: the sonnet is pulverized on the page.

What remains is precisely the trace and delineation of a minimal sonnet. Ratcliffe's lines are inheritors of Mallarmé's poetics of the spatial page, as well as direct contemporaries of Larry Eigner's gaunt and sculptural texts: by their rarefaction on the line, some of the words and syllables from Shakespeare's sonnets are left to their vibration, just as our memory sometimes retains a few words from a text and allows them to echo. With the poetics of vibration, the text concentrates on the "breath" of the "mellifluous" voice Meres saw in Shakespeare's "pleasing sound" (1. 10). Indeed, the web of /s/ /z/ and /w/, the incessant echoes in /wai/, for instance, seem to turn this page into the mountain in the myth of Echo and Narcissus, where the reader/listener is literally lost as he listens to the sounds and the silence which constitute the space of troubled signification. From the lack of words and syntax, from ellipsis and elision, the poem creates a new texture of manifold collisions and interpolations without being able to come to completion. Questions, denoted by "why" and "asked," are legion and call for a multivocal reading through which "some [...] more" is demanded, as a response to the reading process underlying the poem. Taken over by the sounds of the text, one must never forget to think about its texture, i.e. comprehend what is heard and what is seen ("saw" 1. 11).

Through the twists and turns of its lines, this poem is also a text that tries to look for and find another type of sentence, where the word does not have a semantic function only, but has almost reached phonetic and graphic autonomy, as is well shown by the graphic recurrence of <ea> in "breath," "speak" and "pleasing." These act as rhymes for the eye within the text and bring forward what might have otherwise been overlooked when reading Shakespeare's text as a whole. Suddenly the words of the text gain an aesthetic quality and in a movement akin to that of concrete poetry - though this poem is not concrete poetry - the poem goes beyond language and becomes a drawing. Shakespeare's variegated complexities resulting from the copious tropes, the profusion of interconnected sounds and generous details have been done away with. Should we then say that this amounts to killing Shakespeare's texture or, even worse, his words and sacred thoughts because one cannot face the timeless grandeur of his genius? Or should we look at literature from another mode altogether and see this text as a contingent homage to Shakespeare? Who could argue that if Shakespeare's poetic arabesques are no longer explicitly apparent in Ratcliffe's poem, Shakespeare's text has been done away with? It seems, rather, that one could tentatively take up for Shakespare's rereading in the present, Jacques Derrida's words when considering the illusory end of Marxism: when the death of Marxism is being proclaimed, when Marx's end is forecast, Marx comes back to haunt those who speak of his end (69). I'd thus say that Ratcliffe's text is much more a composition-with than a destruction of Shakespeare's

Transatlantica, 1 | 2010 
text. And, tellingly, "with" is the last word of Stephen Ratcliffe's text: "I think / with." The "I" of Shakespeare's text comes back in Stephen Ratcliffe's poem. Yet it is not the "I" of the tombstone nor is it the "I" of a poet thinking of himself as Shakespeare's voice. This "I" transforms Shakespeare's in the present and becomes a polyphonic voice where the speakers of Ratcliffe's text and of Shakespeare's happen to be set in a dialogue pointing the issue integral to contemporary poetry, as well as to Shakespeare's sonnets ${ }^{15}$ : that of the unassignable nature of "I." Reading Ratcliffe's text means that one travels with Shakespeare's text, as a companion. Rather than killing Shakespeare, Ratcliffe's text expresses the author's desire to read Shakespeare, provided one reads my statement with Valéry's anti-idealist statement in mind that "the imagination of desire only sees a corner - a favourable fragment of things... He who sees everything desires nothing and is afraid to move" (603).

In "Shakespeare's Memory," Borges shows that possessing Shakespeare's memory is purely and simply impossible, because the minute the narrator, or anyone, inherits it, he is a split subject with two memories, where one blocks the other. The Faustian pact of wishing to know all of Shakespeare and be the voice of shakespeare's memory soon leads the main protagonist and narrator to wish to empty himself of "Shakespeare's memory" and pass it on to someone else. What Ratcliffe's text suggests is that the desire for Shakespeare does not mean that one should try to speak for Shakespeare, but to try to allow Shakespeare's text to be re-read in the present through a dialogue with his text, or portions thereof. It almost prompts us to read sonnet 130 as an acoustic architecture as well as a drawing.

Such desire also inhabits Jen Bervin's poetic and artistic reading of Shakespeare. This seven-word poem by an artist and poet who favours writing gestures and materiality, comes from Nets (2006), whose title makes explicit the whole project: the book endeavours to strip Shakespeare's Sonnets bare, leaving only a trace, i.e. a few words caught in the net of the text. In a sense, then, her text takes up Ratcliffe's practice - he is thanked at the beginning of the collection. However, the composition one reads on the page is different from Ratcliffe's. Indeed, one reads both the new poem in bold type and Shakespeare's text in grey. The idea of the palimpsest, i.e. the overused metaphor for writing in the theory of the intertext, is given its literal graphic correlative: it is drawn and shown. Yet, this inverts the process at work in the theory of quotation as a text perpetually quoting others. Antoine Compagnon observes that a quotation is "a foreign body in my text, because it does not belong to me, and because I appropriate it" (31, my translation). Here Jen Bervin's new text consists in a selection of a few words on another text. Whereas in a quotation, one borrows from a prior text, one cuts one's material from an older text and leaves the rest of the old text behind, here the new text seems to appear as a quotation within the older material, which the reader can apprehend fully. The layout of the old and the new texts seems to suggest that the new highlighted text in bold type is a foreign body in the density of the older text. While the new text is being traced over the surface of the older text, it doesn't rub it out. The new text becomes a synecdoche of the old one as well as its tangible ghost. This is once again a new literalisation of intertextuality: the eerie phenomenon of a to-and-fro movement between Shakespeare's and the new text experienced with the two other poems commented on above is made apparent on the page itself of Bervin's minimal production. So much so that it is almost impossible for the eyes to focus and adjust 
between grey and bold, thus creating a perpetual ongoing reading whose echoes are almost already traced.

38 A spectral phenomenon ensues: it is hard to know which text comes first and one wonders if there is one text at all. In fact, the impossible movement where both texts are different and identical, questions the notion of appropriation and pushes further the ethical questions underlying the intertextual process: for instance, what distinguishes Bervin's text from plagiarism? How far is Bervin's display of new and old a way to relinquish the violence of appropriation? In what way does this question the integrity and individuality of the author?

In the short note appended at the end of the book, Bervin explains: "I stripped Shakespeare's sonnets bare to the 'nets' to make the space of the poems open, porous, possible - a divergent elsewhere." The text deriving from 130 sends us constantly elsewhere. Because of its grey delineation, the text of the poem allows the reader to actualise Shakespeare's sonnet and then superimpose the author's minimal selection from Shakespeare's 130, which is extremely radical and yet is nothing but the sonnet's very words and, to take radical etymologically, its very root. Indeed, although this is not true of all the poems in Nets, the reinterpretation of 130 is in fact the interpretation of the aporia of metaphors and comparisons that 130 concludes upon. Indeed, once again, Shakespeare's 130 uses the conventional comparisons and metaphors of Elizabethan sonneteers and yet turns them upside down with circumvoluted and paradoxical formulas such as "nothing like," which state and negate simultaneously. Though it concludes on the pejorative "false compare," sonnet 130 functions as a way to articulate the delight in being able to feel both the displacement that constitutes metaphors and comparisons as well as, at the same time, denying them their power and originality. This paradox is exactly what Bervin's text reveals in the exact formula singled out from Shakespeare's text: "such roses / no such roses."

Traced over Shakespeare's sonnet and thus related to Ratcliffe's texts or, even further, to John Cage's writing through, and published by a small press based in New York situated in the field of so-called "innovative" poetry, Jen Bervin's text also plays with Gertrude Stein's iconic phrase meant to rid the rose of all it ever was in Western poetry: a metaphor prior to being either the word rose or a real rose ${ }^{16}$. Bervin's text is a way to figure out what happens when one reads a text in the present: the texts of the past are no longer valuable because they stand in and for the past, but they happen and coexist simultaneously in and with our reading. Thus, temporal relations are blurred and reshuffled. Reading Bervin's text, it almost seems that Shakespeare plagiarised Gertrude Stein by anticipation ${ }^{17}$ : the text from the past has been retraced by and in the present. With Nets, Shakespeare's sonnets are not just a trace, they trace a new text, are traced and delineated by a new text and are a new text.

What is meant by "sonnets" here? The sonnets happen each time as what they are in the present: a ghost of what they might have been and one of their multiple realized or yet-unrealized readings. With Harryette Mullen's sonnet, with Stephen Ratcliffe's reinterpretation and Jen Bervin's palimpsest, it seems that one gets closer to "Shakespeare in the present," i.e. Shakespeare's text not solely envisaged as a classic. The ghostly trace of Shakespeare's sonnets now is the possibility created by these readings, that is, the possibility to read as well as the possibility for the ghost to exist, alive, through renewed readings. 
form of the sonnet has been subjected to the anathema of the most eminent modernists. Yet, in contemporary American poetry the sonnet is no longer solely the sign of conformism or conservatism, illustrated for instance by the way the "new formalists" reread the form. The sonnet has been transformed, inverted, and distorted to the point where it has become one of the forms that experimental poetry uses and composes with ${ }^{18}$. Within this context, writing-with Shakespeare's sonnets is not a sign of nostalgic return to the origins and the wish to bemoan the past grandeur of British literature. Writing-withThe Sonnets means confronting them, paying tribute to them, distorting them and, in a word, altering the Shakespearean form to allow them, perhaps, to be read in the present. In his newly published Ecrits en souffrance, Marc Amfreville makes one of the vital points of this very conception: "[the idea of an a posteriori retroactive transformation] alters the notion of literary heritage, and such thoughts can lead to the idea that [Brockden] Brown transformed our reading of Shakespeare, rather than being simply indebted to him" (75, my translation). Writingwith Shakespeare reconsiders the linear conception of tradition. It seeks to allow reading and creation to mean more than what they are assigned to mean by the will, the testament or the guiding malediction of the deceased author.

The poetics of the three poets analysed here, which we call Writing-with Shakespeare's text, are not about the inhibiting tragic angst of re-reading shakespeare, or about the tremor at the idea of touching his bones. Writing-with is an attempt to livewith and to be accompanied by a textual ghost. It aspires not to fix it and solidify it into a dead albeit impressive statue as might happen when mourning the deceased, but rather, to paraphrase Roland Barthes (2009) speaking about the death of his mother, it tries to give the reader the chance to impart fluidity to the experience of the intertext.

\section{BIBLIOGRAPHIE}

ACKROYD, Peter. Shakespeare, The Biography. London: Chatto and Windus, 2005.

AMFREVILLE, Marc. Ecrits en souffrance. Figures du trauma dans la littérature nord-américaine. Paris : Michel Houdiard, 2009.

ANTIN, David. What it means to be avant garde. New York: New Directions, 1993.

BARTHES, Roland. Journal de deuil. Paris : Editions du Seuil, 2009.

BATE, Jonathan. Shakespeare and the English Romantic Imagination. Oxford: Clarendon, 1986.

---. "Ovid and the Sonnets; or, Did Shakespeare Fell The Anxiety of Influence?," Shakespeare Survey, xlii (1990), 65-76.

---. The Genius of Shakespeare. London: Picador, 1997.

BAYARD, Pierre. Le plagiat par anticipation. Paris : Editions de Minuit, 2009.

BERVIN, Jen. Nets. Brooklyn: Ugly Duckling Presse, 2006.

BLOOM, Harold. The Anxiety of Influence (1973). Oxford: OUP, 1997.

Transatlantica, 1 | 2010 
BONACCORSI, Robert. "Les histoires naturelles de Mickey," in Nicolas Rubinstein, Mickey is Also a Rat. La Seyne-sur-Mer : Villa Tamaris Centre d'art, 2007.

BOOTH, Stephen. An Essay on Shakespeare's Sonnets. New Haven: Yale University Press, 1969.

BORGES, Jorge Luis. “Shakespeare's Memory” (1983), The Book of Sand and Shakespeare's Memory. London: Penguin Books, 1998, 122-131.

COMPAGNON, Antoine. La seconde main. Paris : Editions du Seuil, 1979.

DERRIDA, Jacques. Specters of Marx. The State of the Debt, the Work of mourning, \& the New International. Tr. Peggy Kamuf. London: Routledge, 1994.

DOBSON, Michael. The Making of the National Poet: Shakespeare, Adaptation, and Authorship, 1660-1769. Oxford: Clarendon, 1992.

FLOWER, Joe. Prince of the Magic Kingdom: Michael Eisner and the Re-making of Disney. New York: J. Wiley, 1991.

EDMONDSON, Paul and Stanley WELLS. Shakespeare's Sonnets. Oxford: OUP, 2004.

HOGAN, Patrick Colm, Joyce. Milton and the Theory of Influence, Gainesville: University of Florida Press, 1995.

HUGO, Victor. William Shakespeare (1864). Paris : Flammarion, 1973.

LEVIN, Bob. The Pirates and the Mouse, Disney's War Against the Counterculture. Seattle: Fantagraphics Books, 2003.

LIONNAIS (le), François. "Théorie et histoire ", in Oulipo, La littérature potentielle. Paris :

Gallimard, 1973, 14-17.

MATHEWS, Harry. « Mathews' Algorithm », in Motte, Jr, Warren F.. (ed), Oulipo: A Primer of Potential Literature. Lincoln: University of Nebraska Press, 1986, 126-39.

MAC LOW, Jackson. French Sonnets. Tuscon: Black Mesa Press, 1984.

McCAFFERY, Steve. Seven Pages Missing (vol. 2). Toronto: Coach House Books, 2002.

MELVILLE, Herman. "Hawthorne and His Mosses," in The Piazza Tales and Other Prose Pieces 1839-1860, Hayford Harrison, Alma A. MacDougall and G. Thomas Tanselle (eds.). Evanston and Chicago: Northwestern University Press and the Newberry Library, 1987, 237-253.

MULLEN, Harryette. Sleeping with the Dictionary. Berkeley: University of California Press, 2002.

RATCLIFFE, Stephen. [where late the sweet]BIRDS SANG. Oakland: O Books, 1989.

RUBINSTEIN, Nicolas. Mickey is Also a Rat. La Seyne-sur-Mer : Villa Tamaris Centre d'art, 2007. SCHOENBAUM, Samuel. Shakespeare's Lives. Oxford: Clarendon Press, 1991.

SMITH, Hallett. The Tension of the Lyre, Poetry in Shakespeare's Sonnets. San Marino, Cal.: Huntington Library, 1981.

SOURIAU, Etienne. Vocabulaire d'esthétique. Paris : PUF, 1990.

STEIN, Gertrude. "Poetry and Grammar," in Writings 1932-1946. Eds. Stimpson, Catharine R. and Harriet Chessman. New York: Literary Classics of the United States, 1998.

VALÉRY, Paul. CEuvres, tome 2. Ed. Hytier Jean. Paris : Gallimard, 1960.

VICKERS, Brian. Appropriating Shakespeare: Contemporary Critical Quarrels. New Haven: Yale University Press, 1993. 


\section{NOTES}

1. Among theoreticians of influence, Patrick Colm Hogan calls Bloom's theory into question (6-9) saying, for instance, that Bloom "grossly oversimplifies the multiplicity and complexity of writers' relations to various precursors and their various works" (7). Among the Shakespeareans, Jonathan Bate, criticises Bloom's positions both from the perspective of the Romantics reading Shakespeare (Bate 1986, 1-5) and from that of Shakespeare (Bate 1990). In its first edition, Bloom held that Shakespeare was immune from the "Anxiety of Influence." When Bloom corrected this in his second edition, with his new preface where he discussed the relations of influence that Marlowe supposedly exerted on Shakespeare, Bate further contended that Bloom was mistaken in taking a single-handed view of a unique strain of influence. Yet, to our knowledge, Bate's analyses never reach to some of the theoretical principles of Bloom's assertions as they transpire from his rhetoric. Among poets and thinkers, David Antin makes the same argument in a witty and humorous text: he claims that Bloom completely leaves aside the multivalence of texts and influences. Antin's argument comes as one of the pieces of a contention between Bloom and socalled "innovative" or "experimental" writing, which Bloom dismisses as non-existent (1993).

2. Though I'm not arguing that Bloom refers directly to Hugo, his distaste of the French is so vividly articulated in this text that I doubt he would refer to a French romantic. Yet Bloom's hyperbolic statements of a universal Shakespeare unwittingly echo Hugo's own "Lucrece is the sphere, Shakespeare is the globe" (86).

3. See for instance the growing appropriation by the British Monarch of the celebrations of Shakespeare's anniversaries from the late $18^{\text {th }}$ century to the $19^{\text {th }}$ century. For the rise of Shakespeare's reputation in Britain before the 19th century, see Michael Dobson.

4. Such sentences on the French and on Shakespeare were written in 1997, and cannot simply be dismissed as gross uninteresting caricatures. Similarly, my comments should not be taken as polemical or vain. I am not one to enter into a polemical debate with Bloom, but it seems to me particularly interesting given Bloom's fame and influence as a critic that he should pass these judgments. Moreover, these views are consistent with his nostalgic view of literature and scholarship (for instance, he laments over "the ruined shards" of the Anglo-American academic world [xxv]) that a strain of contemporary American literature opposes.

5. Bloom uses this term to berate the likes of Lacan, Barthes, Foucault and those who apparently espoused their views in the United States and did away with the amount of "genuine" literary criticism. Brian Vickers, a British Shakespearean critic, also develops the same conservative brand of criticism (1993).

6. This is also perhaps why Ackroyd plays with the previous biographies of Shakespeare and the element of fiction in any biography in his own biography of the Bard, wittily entitled Shakespeare: The Biography.

7. For Shakespeare's satire of Petrarchism, see Edmondson and Wells (15 and 91), also see Smith's analysis (59-60). See Booth (180) for Shakespeare's way with poetic conventions.

8. http::/www.archive.org/details/Harryette_Mullen_lecture_on_language_june_2002_02P040

9. This is not too far from Philippe Parreno and Pierre Huyghe's move to rescue AnnLee, a character produced by a Japanese "character company" that specialises in designing and selling comic book characters. Parreno and Huyghe bought the character, designed as a minor and unimportant one, and thus extracted it from the commercial and industrial production it was designed to serve. In Parreno's "Anywhere out of the world" (2000), AnnLee says: "Other characters [sold by the character company] had the possibility of becoming a hero [...] they were really expensive when I was cheap! Designed to join any kind of story, but with no chance to survive to any of them. I/was never designed to survive [...] I / am / a product/ a product freed from the marketplace I was supposed to fill." (http://airdeparis.com/pann2.htm). A whole article could be devoted to such ambiguous rescue of popular culture characters. The "rescue", a word 
that I am using here as a direct gloss of AnnLee's monologue, is not an easy notion. For instance, though the character was saved from pure extinction, it is not made to serve another artistic and commercial realm, described by Raymonde Moulin as the art world. Such questions are also asked in and by Parreno and Huyghe's works "using" AnnLee.

10. In an explicit pun with Shakespeare's famous "dark lady" and her own skin colour, Mullen titles a second parody of 130: "Dim Lady," $(2002,20)$.

11. Bernard Morteyrol, a former head of Studio Disney France from 1970 to 1980 says how much Mickey and other Disney characters are set into conventional types: "everything was drawn according to the 'how to draw', the bible given by the Studio. Each fascicle was devoted to one character and to the attitudes you should respect [in your drawings] [...]. All the drawers were trained onsite according to this bible" (Rubinstein 7). It is such conventions that Harryette Mullen's text, along with other attempts (Rubinstein), suspect.

12. "Harryette Mullen," interview with Christopher Myers, Index Magazine (1999). http:// www.indexmagazine.com/index.shtml

13. See for instance Spenser's sonnet 15 in Amoretti and Epithalamion, where the revered body of the praised woman is almost turned into a chest bedecked with precious gems before her mind "adorned with virtues manifold" (1. 14) turn her into a disembodied neoplatonic idea that "few behold" (1. 13).

14. According to the founder of the Oulipo, François Le Lionnais, "the analytic trend [in Oulipo] elaborates on texts from the past to look for possibilities that often go beyond what the authors suspected" (17).

15. The famously problematic nature of the "I" in Shakespeare's sonnets has generated an incredible wealth of literature : from those who assign "I" to Shakespeare himself to those who, like Booth, read the "I" as a speaker unrelated to the man-Shakespeare.

16. Referring to "a rose is a rose..." Stein argues that "in that line the rose is red for the first time in English poetry for a hundred years" (327).

17. Plagiarizing with anticipation is a notion coined by the Oulipo and developed recently by Pierre Bayard in Le plagiat par anticipation.

18. Among other experimentations on Shakespeare's sonnets, read Jackson Mac Low's French Sonnets, Harry Mathews "Mathews' Algorithm" and Steve McCaffery's "translations" of sonnet 1 and 105 (McCaffery 161-162).

\section{RÉSUMÉS}

Cet article étudie trois réinterpretations du sonnet 130 de Shakespeare par trois poètes expérimentaux des Etats-Unis. Après avoir relu la théorie d'Harold Bloom telle qu'il l'applique à Shakespeare dans The Anxiety of Influence et l'avoir rapidement mise en contraste avec celle de Jacques Derrida dans Spectres de Marx, cet article montre que les textes de Harryette Mullen, Stephen Ratcliffe et Jen Bervin ne font pas de Shakespeare un fantôme de la malédiction. Ils tentent plutôt de vivre-avec Shakespeare dans le présent, nous amenant ainsi à reconsidérer la théorie de l'intertexte.

This article studies three interpretations of Sonnet 130 by three American experimental poets. Rereading Bloom's considerations on Shakespeare in The Anxiety of Influence and comparing them with Jacques Derrida's Specters of Marx, this article shows that rather than thinking of 
Shakespeare as a cursing ghost, Harryette Mullen's, Stephen Ratcliffe's and Jen Bervin's texts reveal Shakespeare as a ghost and a host. Their texts are attempts to live with Shakespeare in the present, thus prompting us to look back on the theory of the intertext.

INDEX

Keywords : Shakespeare, experimental poetry, theory, reception of Shakespeare, H. Bloom, Harryette Mullen, Stephen Ratcliffe, Jen Bervin

Mots-clés : Shakespeare, poésie expérimentale, théorie, reception of Shakespeare, H. Bloom, Harryette Mullen, Stephen Ratcliffe, Jen Bervin

\section{AUTEUR}

VINCENT BROQUA

Université de Paris Est 